\title{
OBSTACLES TOWARDS THE ACHIEVEMENT OF GENDER EQUALITY IN THE BALTIC STATES: INSTITUTIONAL AND VALUE DIMENSION
}

\author{
Nataliia KHOMA \\ Professor, Political Science and International Relations Department, Lviv \\ Polytechnic National University, Ukraine \\ E-mail: nataliia.m.khoma@lpnu.ua
}

\section{Vasyl KOZMA}

Associate professor, Social Sciences and Humanities Department, National University of Ukraine on Physical Education and Sport, Ukraine E-mail: kozma_v@meta.ua

\begin{abstract}
The problem of implementing the gender equality principle in post-totalitarian government in the Baltic states is considered in the context of the slowing of liberal democratic modernization in the past decade. Our goal is to identify obstacles to the establishment of gender parity in Estonia, Latvia and Lithuania at the institutional and value levels. The stagnation in the deepening of the liberal democracy's values, including the values of gender equality, is related to the processes of political radicalization, several crises in recent years within the EU, slow changes in the values of the Baltic population, as well as other reasons. The cases of Estonia, Latvia and Lithuania are analyzed according to the following criteria: gender pay gaps, level of gender-based violence, level of women's participation in decision-making processes, presence/absence of gender quotas and gender-based budgeting. The results showed the disparity in the practical policy of the Baltic states with the existing legal guarantees of gender parity. A particular emphasis of the study has been placed on the value level, through the prism of which the causes of resistance to gender-oriented initiatives, ascending anti-gender and intolerant discourse have been investigated. The inconsistency of the political and legal awareness of the population of the Baltic states of the fundamentally important EU standards for values of liberal
\end{abstract}


democracy, in particular gender equality and non-discrimination, is proved. It is argued that the institutionalization of the principle of gender equality in the Baltic States is influenced by the peculiarities of the political and legal culture of the population, the preferences of civil society. The instability of the liberaldemocratic characteristics of culture has the effect of displacing the demands of the Baltic communities to state institutions to establish a consistent policy of gender equality. The weakness of public demands on gender equality has been shown to be one of the main obstacles to achieving high standards of gender equality in the Baltic States.

Keywords: liberal democracy, principle of gender equality, gender parity, Baltic states.

\section{Introduction}

A quarter of a century ago, a fundamental international legal act, the Beijing Declaration and Platform for Action (1995), called on signatory countries to take the necessary measures to remove all obstacles to gender equality. Since then, progress in the practical implementation of the gender equality principle has increased significantly but is still insufficient, as various forms of genderbased discrimination are more or less common in all states. Despite the image of the EU as a liberal democratic community of states, the issue of gender equality is still an issue for most member states. So far, no single country has achieved full gender equality. Since the second half of the 1990s, anti-gender campaigns have started growing, despite long-standing traditions of democracy in Europe (Paternotte, Kuhar, 2018, p. 14) which have their origins in the initiative of the Roman Catholic Church (and later in other churches) and have been strengthened by the right-wing populist movement (Verloo, 2018). Gender gaps persist in employment, wages, and access to job positions, and against the backdrop of quarantine restrictions in 2020, they have widened. Therefore, eliminating gender inequalities remains an urgent task of the EU, as declared in "A Union of Equality: Gender Equality Strategy 2020-2025."

The problems of the gender gap have been manifested particularly in the new democracies of Central and Eastern Europe, which have joined the EU in the last few enlargements. Over the past decade, these countries have slowed down liberal democratic modernization, both at the institutional and value levels, including in terms of achieving gender parity. The post-Soviet Baltic states of Estonia, Latvia and Lithuania, which have been full members of the EU since 2004, despite significant progress in implementing the gender equality principle, remain quite stark cases of gender inequality in Europe. The population of the Baltic States, given the peculiarities of the political and legal culture of the most population, is not characterized by a pronounced willingness 
to support the implementation of gender equality in all its manifestations, consistently require the authorities to implement decisions already taken, to deepen reforms aimed at strengthening gender parity. Even those reforms aimed at guaranteeing gender equality, which are being implemented by the authorities at the request of the EU institutions, do not raise widespread support and approval of the Baltic States' population.

This resistance has a pronounced conservative basis. In our opinion, in the communities of the post-Soviet Baltic states, a number of stereotypes remain, which lead to "Glass Ceiling", "Glass Wall" and other destructive phenomena. The authors have challenged themselves to determine the range of problems in the implementation of the principle of gender equality in the Baltic States pointing to the common trends and national characteristics of the three states; to find out what factors (institutional and value) lead to the fact that Estonia, Lithuania and Latvia do not meet the EU standards for the implementation of the principle of gender equality.

\section{Methodology}

The implementation of the gender equality principle by an EU member state is an important criterion for the EU in terms of assessing a country's compliance with liberal democratic values. Fulfilling the primarily political Copenhagen criteria in the late 1990s and early 2000s, Estonia, Latvia and Lithuania implemented reforms aimed at the inviolability of human rights, including gender equality.

The integration of the Baltic states into the EU has become a tool to increase the range of liberal democracy. In this way, the "democratization through integration" concept was introduced (Dimitrova, Pridham, 2004). In the run-up to the largest expansion of the EU in 2004, there was a popular hypothesis that the European perspective "would restrain extremist and populist tendencies" (Bayer, 2002). This hypothesis, from what we see today of the political processes in Central and Eastern Europe, has not been confirmed; the defects of democracy are growing.

The two main theories in which the regime transformations in new EU member states were considered after the fifth wave of EU enlargement were the following: the theory of retreat proved the possibility of a fairly rapid postintegration deformation of the democratic regime by neo-authoritarianism and populism. The alternative argued that European integration will lead to the increase in the quality of democracy, a position dubbed "The Euro Straitjacket". Since 2010, researchers have increasingly shown solidarity with the view that the quality of democracy in European post-totalitarian states has been deteriorating (Kochenov, Magen, Pech, 2016; Sedelmeier, 2014). The current processes of democratic backsliding have proved the validity of the first of these theories, though the Baltic states, which we have analyzed, are not yet striking examples of illiberal democracies, such as Hungary or Poland.

In our view, the Baltic states are examples of stagnation rather than regression with regard to liberal democratic reforms. Such a slowdown is facilitated by the rise to power of populist, conservative, and nationalist political parties. This has 
resulted in the escalating of hate speech, ascending anti-gender and intolerant discourse, criticism of EU and international community initiatives on gender equality. In fact, after the completion of the European integration process, the liberal consensus in post-totalitarian states gave way to illiberal populism (Krastev, 2007). The refusal of Lithuania and Latvia to ratify the Istanbul Convention is one of the vivid proofs of this.

S. Szomolány and Z. Gál, analyzing the problems of the quality of democracy in Central and Eastern Europe, rightly note that "democratic institutions seldom consolidate permanently. Rather, they remain fragile and vulnerable to reshaping by the key political actors - political leaders and elites." (2016: p. 67). The cases of the Baltic States illustrate this in terms of the complexity of the progressive movement towards gender equality and the incontestable guarantees of implementation of this liberal-democratic principle.

Important reforms in the practical implementation of the principle of gender equality have been hampered by their slowdown, not least due to the enhancement of the positions of conservative and nationalist political actors. At the same time, in our opinion, the EU does not make appropriate efforts to protect liberal democratic principles, including gender equality in those member states where these still fragile principles are being undermined. The question of whether there are effective mechanisms in the EU arsenal to solve the problem of democratic deficit in the countries of the latest waves of EU enlargement remains acute (Kelemen, 2017, p. 230).

In almost all countries that have joined the EU since 2004, democracy has been in crisis in the last decade with liberal democratic values are narrowing as well (Müller, 2014). The new European democracies, such as Estonia, Latvia and Lithuania, are significantly more vulnerable to such challenges due to weaker democratic institutions and the relatively short experience of liberal democracy (Krastev, 2016). Here, a new anti-liberal consensus is rapidly being constructed, which has rising support even among the generation that has achieved adulthood after the fall of the totalitarian regime (Krastev, 2018). The financial crisis, migration crisis, the eurozone crisis and other crises, including the COVID-19 pandemic, call into question the stability and quality of liberal democracy and undermine the legitimacy of the democratic political order. At the same time, it is obvious that threats to the values of liberal democracy, including gender equality, come not only from the top, including governments but also from citizens given the commitment of many people to illiberal values (Norris, Inglehart, 2019).

The problem for the stability of the principles and values of liberal democracy, including gender equality, in such post-totalitarian countries as the Baltic states, is that post-1989 regime transformations have given priority to economic reform over civic improvement (Szent-Iványi, Tétényi, 2008). That is, liberal democratic norms and practices have not been consistently and purposefully "embedded" in these societies. We see this as one of the significant causes for the current slowdown in support for gender equality at the institutional, and especially at the value level. 
The current resistance to the norms and values of liberal democracy can be explained to some extent by the policy of "normality", when the main task for post-totalitarian states was to follow the West to become "normal" (Krastev, Holmes 2018, p. 118). The path to "normality" was to import liberal democratic institutions, a public endorsement of Western liberal values. Such a literal emulation of Western models provoked negative moral and psychological consequences, one of which was the rise of conservative, nationalist political parties and the popularity of their ideas among the population. The ideas of such political actors are increasingly supported in the Baltic states and Central and Eastern Europe in general.

The joining of the Baltic states to the EU has not guaranteed their rapid liberal democratization, particularly at the value level. It is reflected in the inconsistency of the political and legal awareness with values of liberal democracy, in particular, gender equality and non-discrimination, which are fundamental for EU. The problem is exacerbated by the EU's insufficient attention to the lack of progress by some member states in achieving gender parity, although the EU has repeatedly stated its readiness to invest in deepening the resilience of modern liberal democracies.

To study these processes, the case study method was used (cases on the implementation of the principle of gender equality have been studied), a comparative method (search for common trends and specific features of the implementation of the principle of gender equality in Estonia, Latvia and Lithuania). During the preparation of the study, international legal norms, EU regulations and national acts of the Baltic States on the prevention of discrimination based on sex were processed. Attention has been given to the gaps between the declared gender equality and the actual problems in the implementation of this principle.

The logic of the analysis assumes that all three countries should be compared according to clearly defined indicators. This facilitates clear identification differences within specific criteria for comparison. However, in the study of the three cases, a large number of national features of the implementation of the principle of gender equality were revealed, which are common for specific states and not inherent in others. This made it difficult to follow a clear logic of comparative analysis.

\section{Institutional and value barriers to Lithuania's compliance with EU policy on the implementation of gender equality principle}

The movement for gender equality in Lithuania has a long history and dates back to 1905 when the Lithuanian Women's Association was founded. For more than a century, since 1818, Lithuania has given women the right to vote, which happened earlier than in many liberal democracies. The occupation of Lithuania by the USSR in 1940 put an end to the liberal democratic evolution of the women's movement and the struggle for gender parity although a policy of sex equalization was implemented within the USSR. A new stage in the 
development of the women's and human rights movement is associated with the resumption of the Republic of Lithuania's independence in 1990.

The current state of affairs regarding the implementation of the gender equality principle is not in line with the ascending pace that Lithuania took in the 1990s. The Constitution of the Republic of Lithuania (1992) enshrines nondiscrimination, in particular gender-based non-discrimination, in statute (Article 29). In 1998, already moving toward EU membership, Lithuania adopted the "Law On Equal Opportunities for Women and Men", which came into effect on March 1, 1999 and which is still in force. This was the first legal act of its kind in Central and Eastern Europe. The Office of the Ombudsman for Equal Opportunities has been operating since 1999. The state regularly adopts targeted programs aimed at implementing the principle of equality (four during the period 2003-2020). However, despite these institutional steps, the situation with the guarantee of gender equality in Lithuania is currently problematic, especially in comparison with the EU leading states.

To assess compliance with the gender equality of the particular EU Member State, we examined the data from the Gender Equality Index, which is a tool to measure the achievements of states in the establishment of a gender equal society. The Lithuanian Index of 2019 achieved less than 55.5 points out of 100 , which is one of the lowest indicators in the EU, the 23rd place. (Gender Equality Index. Lithuania. 2019, 2020). There is an obvious decline in recent years as Lithuania was in 19th position in 2017. There is a slower pace of Lithuania's progress towards gender parity than in most other EU countries. With 56.3 out of 100 points, Lithuania ranks 22nd in the EU on the Gender Equality Index 2020.

According to a 2019 Pew Research Center survey, gender equality is significant for $88 \%$ of Lithuanian respondents. This seemingly high percentage is the lowest in the EU: in Sweden, France and the Netherlands a gender parity is supported by $99 \%$, and in Germany and Spain-98\%. On the other hand, support for traditional gender roles and non-egalitarian marriage is firmly entrenched in Lithuania. A gap in the commitment to gender equality between men (54\%) and women $(68 \%)$ is also typical for Lithuania. By comparison, in the USA, men are even more likely $(93 \%)$ than women $(89 \%)$ to support the idea of gender equality (European Public Opinion Three Decades After the Fall of Communism, 2019, p. 90-97).

One of the most complex challenges regarding gender equality in Lithuania is discrimination against women in the labor market. Since 2011, the wage gap between women and men has been steadily widening. In 2018, women's gross salary in Lithuania was $14.4 \%$ lower than among men. In addition to differences in wages, a significant division of employment into "female" and "male" (horizontal segregation), can be observed in Lithuania.

In 2020, Lithuania began discussions at the expert and social level on the formats for the implementation of the Work-Life Balance Directive (Directive (EU) 2019/1158, 2019). The provisions of this EU act are aimed at changing the rules of the game for men and women; these rules support an equal division of responsibilities that will enable women to remain in the labor market and 
take on senior positions. However, opposition to the implementation of the directive has developed by the Lithuanians. This opposition has been criticized by NGOs working to promote gender equality.

The share of women in the Lithuanian parliament is one of the lowest in the EU. According to the results of the democratic elections to the Lithuanian legislative branch, the Seimas, in $1992,7.1 \%$ of women entered the parliament, while in 1996, 16.8\%. However, in the next elections which were held in 2000, the number of women in parliament dropped to $10.6 \%$; in 2004 the share of women was 22\%, in 2008, 18.4\% (Matonytè, Mejere, 2011, p. 111), 2012, $23.1 \%, 2016,24 \%$. According to the results of the 2020 elections, 27\% of women (38 out of 141 deputies) joined the new Seimas, but some quantitative growth is not a measure of a steady upward dynamics of women's representation in the highest legislative body of Lithuania. Transformation of the political agenda for women and change of decision-making style by the authorities is possible only when political structures are represented by at least a third of women (Dahlerup, 2006).

Since the beginning of the multiparty system in Lithuania, political parties have declared their intention to fully implement the principle of gender equality. This was reflected in the representation of the women voters' needs in party programs. Some Lithuanian parties created even women's wings of their organizations. Meanwhile, the parliament does not support the gender quotas issue. On one hand, the idea of gender equality seems to have received institutional support in Lithuania in recent decades (not least through EU efforts), but at the same time, open and latent opposition to it is growing. The Lithuanian political elite does not have a strong understanding that gender quotas are an essential tool for reducing gender imbalances in politics. Currently, only the mechanism of voluntary party quotas is used in the elections to the Seimas of the Republic of Lithuania. In particular, only the Social Democratic Party of Lithuania from the parliamentary political parties in 2016 has committed to such quotas. Among the reasons for the lack of legislative gender quotas in Lithuania are normative and value factors related to the patriarchal attitudes of the Lithuanian political elite, as well as the attitude toward gender quotas as a certain revival of the Soviet heritage (Mejere, 2012, p. 58).

Even after the state was headed by a woman, D. Grybauskaite, for the decade from 2009 to 2019, women's representation at the highest political levels remains limited, and gender equality continues to be a minor political issue in public discourse (Matonytè, Mejere, 2011, p. 124). Although Lithuanian women hold top state posts, they rarely have the opportunity to influence policy development. This happens because they are less integrated into existing informal social networks, actual decision-making groups that generate ideas for future policy steps (Jurènienè, 2010, p. 4). In fact, the role of various informal mechanisms remains significant, despite the understanding of their primarily destructive nature, in the post-Soviet space.

The situation concerning representation of women in Lithuanian politics is quite clearly marked by the current opinion of the French philosopher L. 
Irigaray, who expressed several decades ago that although women have opportunities in politics, they are partial and local. And these opportunities are only concessions from the current government, but not the assertion of new values (Irigaray, 1994).

We share this opinion, because it is the change in society's values, and not only the positions of state or supranational institutions, that depends on the implementation of the principle of gender equality in a particular country. In the axiological dimension, there is still opposition in Lithuanian society.

As well as politics, education, science and other spheres are still not genderbalanced in Lithuania. A study of gender parity in Lithuanian universities confirmed the existence of asymmetric gender distribution and vertical segregation in the Lithuanian higher education (Žalènienè, Krinickienè, Tvaronavičienè, Lobačevskytė, 2016, p. 237). Women dominate at the lowest level of administrative and scientific positions, while men dominate at the highest levels of the universities' educational and scientific hierarchy. This situation requires revision from the perspective of gender equality.

At first glance, Lithuanian citizens, as part of an EU member state, would have to cherish gender equality as an important stimulus for social changes and progress. However, too many Lithuanian women still do not have "courage and active attitude in the realization of their equal opportunities, retain dogmatic and stereotypical thinking about genders, expanding the concept of women's rights" (Pavilionienè, 2015, p. 277). This testifies to the still significant role of patriarchal approaches to the status of women in Lithuanian society, which is still characterized by conservative sentiments, which hinder the introduction of gender parity. One indication of the Lithuanian community's conservatism is that initiatives to implement the principle of gender equality come more from outside, first the USSR, and now the EU, than by local initiatives (Žvinkliene, 2009, p. 353).

Indirect forms of discrimination against women are obvious. For a long time, it could be observed in the surname of women, when the structure of the wordsurname reflected the women's social status (Čepaitienè, 2004, p. 21). The suffix in the surname depended on whether a woman ${ }^{1}$ takes the name of the father or the husband. This practice violated the women's privacy of marital status but was justified by a large part of society as a centuries-old ${ }^{2}$ tradition of Lithuanians. However, since 2003, the formation of female surnames has been simplified at the legislative level: women are allowed not to form a surname with certain suffixes. At the same time, several discriminatory restrictions for women concerning the formation of their surnames still persist. It should be noted that, on the one hand, Lithuanian women are increasingly aware that the right not to have a surname with a mandatory suffix as they have become aware

\footnotetext{
${ }^{1}$ For example, the surname of a man is Sauliūnas, a married woman or a widow has Sauliüniene surname while an unmarried woman's last name is Sauliünaite. In the Lithuanian tradition, there are several types of suffixes, which are used to form female surnames, adding to the root of the surname of the father or husband.

${ }^{2}$ Suffixes in surnames of the 16-18th centuries were primarily based on property-legal relations and questions of inheritance.
} 
of the right to choose the information they want to disclose about themselves. On the other hand, after the introduction of spelling surnames' innovations came into force in 2003, the change of surnames to neutrals did not become widespread among Lithuanian women. Instead, society periodically intensifies the discussion about the inexpediency of giving up surnames without suffixes in view of the Lithuanian tradition. The main argument is the point about the destruction of the unique heritage of the Lithuanian nation by such changes in anthroponymy. The fact that the issue of women's surnames was first raised in 1998 is also significant in the argumentation of the conservatism of Lithuanian society (Jurenienè, 2010, p. 5). It was then that the Lithuanian women's initiative group appealed to the European Court of Human Rights, relying on the European Convention on Human Rights ${ }^{3}$, which guarantees the right to privacy while protecting a person's marital status.

Domestic violence against women remains a challenge for Lithuania: one in three women experiences it in one form or another. In 2013 domestic violence was criminalized. In 2019, according to the Department of Statistics of the Republic of Lithuania, 53,000 reports of domestic violence were recorded; at the same time, the number is growing rapidly, for example, in 2012 more than 18,000 reports were recorded (Apsauga nuo smurto artimoje aplinkoje, 2020). A large number of illegal acts related to domestic violence remain undeclared and, as a result, unpunished. At the same time, a significant part of Lithuanian society considers certain sorts of domestic violence acceptable.

Lithuania, as well as Latvia, is among the small number of EU states that have not ratified the Council of Europe Convention on the Prevention and Combating Violence Against Women and Domestic Violence, the Istanbul Convention. In 2013, the Istanbul Convention was signed but not yet ratified by parliament, which formed a strong anti-convention opposition. Opponents believe the reason for resisting the act's ratification is in the imposition of a gender ideology that does not protect against domestic violence but significantly harms the moral principles and family values of Lithuanian society (especially transgender people). In our opinion, there is currently no political will to ratify such an important document from a gender-based perspective in Lithuania.

\section{Implementation of the gender equality principle in Latvia with conservative component dominating in political and legal culture}

The institutional arrangement for the implementation of gender equality in Latvia began to take shape in 1999, when the Ministry of Social Security was responsible for developing gender equality policy. In the next two decades, Latvia failed to move closer to an effective, consistent gender equality policy. It is premature to state that Latvia emphasizes the gender aspect in its policy. Prior to the European integration process, gender equality issues were not at the

\footnotetext{
${ }^{3}$ The court dismissed the case due to the fact that the case was not initially considered by the Republic of Lithuania's courts.
} 
top of the political agenda at all. It was the need to meet the requirements for EU candidate countries and the subsequent status of the member state that contributed to the inclusion of gender equality in the country's political agenda. In the Gender Equality Index for 2019, Latvia ranked 18th among EU countries (59.7 out of 100 points) (Gender Equality Index. Latvia. 2019, 2020). These are better positions than Lithuania (23rd in the EU), but Latvia's position is still lower (by 7.7 points) than the EU average. At the same time, there is a strong growth trend of the index in Latvia, which has been increasing steadily since 2005. With 60.8 out of 100 points, Latvia ranks 17th in the EU on the Gender Equality Index 2020. However, despite the obvious positive dynamics in Latvia, a number of problems in the implementation of the gender equality principle remain.

Latvian law prohibits all forms of gender-based discrimination (Dimitrovs, 2012). The Constitution of the Republic of Latvia (Article 91) provides that all people in Latvia are equal before the law and the courts. Human rights are realized without any discrimination. However, there is no constitutional norm on gender equality or separate law that would regulate the issue of gender equality in Latvia. At the same time, the laws and regulations in force in Latvia provide mechanisms to prevent all kinds of gender-based discrimination. First, the principles of gender equality were introduced into labor relations, and over time they were brought into other spheres of social life.

The Concept Paper on Gender Equality Implementation (2001) set out the task of integrating a gender approach to the development, implementation and maintenance of gender equality. This document provides the basis for the development of further action plans and documents. As a result, gender issues were highlighted in each of the political action plans adopted by the Latvian government in 2004, 2007, 2012 and 2018. These plans have consistently focused on the establishment and functioning of sustainable institutional arrangements that would promote the implementation of the gender equality principle.

The Government Act of the Republic of Latvia called "Plan for the Promotion of Equal Rights and Opportunities for Women and Men for 2018-2020" aims to promote the integrated implementation of gender policy. This document is formally in conformity with the EU Roadmap for Gender Equality and sets out the main areas for action: promoting economic independence and equal opportunities in the labor market; promotion of equal educational opportunities; reducing the prevalence of gender-based violence; strengthening the effectiveness of the authorities in gender equality; educating the public on gender issues. However, there are serious discrepancies between planned, implemented, and the current deterioration of socio-economic indicators due to pandemic restrictions having led to the suspension of many planned projects. There is no specialized gender unit in the Latvian Seimas. These issues fall within the competence of the parliamentary Commission on Human Rights and Public Affairs. However, the commission's activity in gender issues is insignificant, and recently its activities have been mainly associated with 
criticism of the Istanbul Convention and arguments for the inexpediency of its ratification by parliament.

Strong gender stereotypes and gender segregation in the labor market and education as well as persistent gender pay gaps remain challenges. The EU estimated that Latvia has one of the highest numbers of people in the EU who find it difficult to reconcile work and family life (Dzimumu līdztiesības politika Latvijā, 2015, p. 4).

One of the important aspects of gender equality is women's representation in government. Women received voting rights in Latvia, as well as in Lithuania ${ }^{4}$, in 1918, and the first female member of parliament, Berta Pipina, was elected in 1931. The 2018 Seimas of the Republic of Latvia includes 31 female deputies, which is the largest women's representation in the history of Latvian parliamentarism. The Seimas of the previous convocation (2014-2018) included 19 women. It would be premature to endorse this growth of women's representation in Latvia is a steady trend, but signs of this process have been shown. There are no legislative gender quotas in Latvia. There are only voluntary party quotas, but in the last parliamentary elections (2018) only the "Unity" (Vienotība) center-right party proposed almost $40 \%$ of female candidates on its party lists, probably aiming to gain as many women's votes as possible.

Concerning the executive branch, as of February 1. 2021 two ministerial positions out of 14 in the Latvian government are held by women. In the years since Latvia's independence, only one woman, Laimdota Straujuma, has served as head of government. One of the six presidents of the independent Republic of Latvia was a woman, Vaira Viḳe-Freiberga. At the municipal level, Latvia also has a relatively high proportion of female MPs: $34 \%$ of elected deputies were women in the elections of 2017. Among mayors, women accounted for $24.4 \%$.

One of Latvia's controversial problems on the path to gender parity is the refusal of the Seimas of the Republic of Latvia to ratify the Istanbul Convention. The issue of ratification has been postponed. On August 3, 2020, the Constitutional Court of the Republic of Latvia initiated proceedings on the compliance of this international legal document with the Basic Law of the Republic of Latvia. Certain norms of the Istanbul Convention were challenged by Latvian deputies as being interpreted to be inconsistent with family and Christian values, which form the identity of the Latvian state and as undermining the resilience of the traditional family. The Latvian deputies of the Seimas are concerned about the contradiction of the Istanbul Convention with Art. 110 of the Constitution of the Republic of Latvia, according to which the state has already made commitments to protect, support marriage a the union between a man and a woman, family, and the rights of parents and children. Politicians who are critical of the Istanbul Convention take the view that this international legal act expresses an artificially modeled concept of social gender disguised in legal terminology to impose on society ideological orientations that are incompatible

\footnotetext{
${ }^{4}$ In the third Baltic state, Estonia, women acquired the right to vote a year later, in 1919.
} 
with the natural concept of human rights. It is worth mentioning that most of the leading political forces in Latvia, as well as the legal doctrine of this state, adhere to the classical, conservative interpretation of the family institution (Sagatys, 2010, p. 194).

Historically, women in Latvia have a high-level of participation in the labor market and a high level of education. The number of women with higher education is growing, but there are strong gender stereotypes in employment. Segregation in the educational as well as professional sectors leads to a pay gap between men and women. The salary of Latvian women is $15.9 \%$ lower than that of men.

Gender-based violence remains a major problem for Latvia. Compared to other EU countries, women in Latvia are more likely to suffer from violence, especially physical abuse. About one in three Latvian women have experienced some form of domestic violence during their lifetime, while men usually face such violence mainly outside the family. A significant proportion of females who suffered violence did not report these illegal actions to either law enforcement or the support services for those affected by violence. This situation is typical not only in Latvia, but it is right here that a large number of women have suffered from various forms of violence $(32.1 \%)$, but have never informed anyone about this physical abuse they have suffered. This figure is twice the EU average (Gender equality indicators. Violence, 2020). Obviously, there are reforms at the institutional level to mitigate this problem, such as amendments to the Criminal and Civil Codes to combat violence against women, but overall, the state's efforts are insufficient.

So far, Latvia has failed to establish a strong and consistent gender equality policy. Although the state points out that it has made significant efforts at the institutional level to implement the principle of gender equality, sufficient measures for gender equality have not been taken. To adopt a specific law in Latvia on gender equality under its international legal obligations to combat stereotypes and discrimination is desirable. International institutions, especially at the EU level, have repeatedly drawn the attention of the Latvian authorities to the need for gender-based budgeting as an currently recognized tool effective to achieve gender equality, which contributes to improving the efficiency of budget funds.

Political and legal culture is characterized by the long-standing view of inequality between women and men at work and during the performance of social activities, which is considered acceptable and even to some extent positive. Latvians' general awareness of gender equality issues is rather limited among the general public; even civil servants are characterized by insufficient gender competence.

In our opinion, Latvian society lacks a real understanding of the importance of gender equality. General awareness of a wide range of gender equality issues is low. Patriarchal family values remain the traditional cultural values of Latvia; freedom from patriarchal stereotypes is not yet peculiar to Latvians. Traditional family values are actively supported by conservative, nationalist political 
actors, as well as major religious communities that have a significant impact on Latvia.

\section{Obstacles to a deepening of gender reforms in Estonia under rising conservative and radical authorities' policy}

Estonia, like other post-totalitarian states in Central and Eastern Europe, has a unique history of gender equality evaluation: from national movements for women's rights before World War II to women movements imposed by communists. The movement for the protection of women's rights and gender equality has been evolving in Estonia since 1882 when Natalie Johanson-Pärna, first spoke publicly of Estonian women education. Since then, women's liberal democratic activism had a positive upward trend until the Soviet Union began to use the role and rights of women as an element of state propaganda in the 1940 s by extolling the heroic labor of a Soviet woman. Estonia, as well as Latvia and Lithuania, was a part of the USSR for 50 years, which had an adverse effect on the values and attitudes of the population to gender roles in the society of these countries. World War II and Soviet repression significantly reduced the male population, and women had to take on traditional male roles. Subsequently, the Communist Party of the USSR controlled the "right" balance of men and women in the political and governmental bodies of Estonia (Grachev, Rogovsky, Rakitski, 2007).

Currently, Estonian women face the dilemma of reconciling the expectations of a still more patriarchal, conservative society's understanding of the role of women as mother, wife, sitter, etc. with Western liberal democratic tendencies and initiatives aimed at promoting equal opportunities for genders. Although by way of cultural roots, Estonia belongs to the group of Nordic countries, gender egalitarianism in Estonian society is much lower than in Norway or Sweden (Alas, Kaarelson, 2008, p. 13).

Market reforms launched after Estonia's declaration of independence have had a stronger impact on women than other reforms. In the 1990s, female unemployment comprised 38.3\% versus $24.7 \%$ among men (Alyanak, 1999). At the same time, women's wages were lower despite their often-higher educational level and qualifications. Horizontal gender segregation, the "glass walls" were already evident in Estonia at this time and still persist.

Estonia started paying attention to the issue of gender equality in the first half of the 1990s, during the start of the European integration process. In 2004, the Law on Gender Equality was adopted, which was supplemented in 2009 by the Law on Equal Treatment. The Gender Equality Commissioner's institution has been operating since 2005. It should be noted that the existence of a legal act on gender equality, as well as the presence of the Ombudsman institution for gender equality distinguishes Estonia from Latvia, where these two important basics for guaranteeing gender parity do not exist. However, although Estonia is at the forefront of many issues, pronounced gender inequality remains a problem. Traditional gender roles in Estonia are very resistant to change; the actual distribution of roles in families remains stable and is slowly adjusting 
towards liberal democratic values. Given the prevailing traditions, the population stereotypically is supportive of conservative values, which are inconsistent with liberal-democratic principles of gender equality. In general, this is a problem for Central and Eastern Europe's nations, even for those that have been integrated into the EU for almost two decades but are very painfully still being transformed.

At the same time, some positive progress in implementing gender policy is noticeable in Estonia. The gender equality index of this country for 2019 was 59.8 points (17th place in the EU) (Gender Equality Index. Estonia. 2019, 2020). At first glance, this is not very high achievement. However, during the 2005-2017 period, this indicator increased by 7.6 points. Also, despite the numerous existing problems, Estonia has the best position in terms of gender equality in the group of Baltic countries. With 60.7 out of 100 points, Estonia ranks 18th in the EU on the Gender Equality Index 2020.

Promoting gender equality is the responsibility of the Ministry of Social Affairs of the Republic of Estonia, in particular the advisory body of the Ministry of Gender Equality Council. Information pages of both the Ministry ${ }^{5}$ and the Council $^{6}$ show low activity of the executive branch in combating gender stereotypes, minimizing various forms of gender inequality in 2017-2018, and lack of information on activities in 2019-2020. This would suggest that at the governmental institutional level gender issues remain secondary and are often raised as a forced response to the demands for certain reforms, voiced from outside, mainly by the EU. In the midst of the global COVID-19 pandemic, it seems that gender issues in Estonia have receded further into the background.

The Riigikogu's, Estonia's legislative body, last convocation included 29 women, which was $28.7 \%$ of the parliament. This is the highest percentage of women in the history of Estonia, although slightly lower than in Latvia and Lithuania. There are neither legislative nor voluntary party quotas in Estonia.

It should be noted that with the strengthening of the Conservative People's Party of Estonia (EKRE) after the parliamentary elections of 2019, the anti-gender discourse has intensified. The party has launched a consultative referendum in the autumn of 2021 to determine more accurately the concept of the family. Estonian high-ranking officials, especially those characterized by radical, conservative ideology, demonstrate gender-biased rhetoric. For example, the Minister of Internal Affairs of Estonia, Mart Helme, described the President of the Republic of Estonia, Kersti Kaljulaid, as an "emotional woman". This fact was recorded after the head of state left the oath ceremony of the Minister of Foreign Trade and Information Technology Marti Kuusik, a member of EKRE, who was accused of domestic violence against his wife. Another example of Mart Helme's gender-biased rhetoric concerned the appointment of Sanna Mirella Marin as Prime Minister of Finland at the end of 2019. During the talk show, Mart Helme publicly voiced opinions concerning the Finnish

\footnotetext{
${ }^{5}$ See: https://www.sm.ee/en/gender-equality-and-equal-treatment. Note that the last update of this page was on July 13, 2017 (data as of September 21, 2020).

${ }^{6}$ See: https://www.sm.ee/et/soolise-vordoiguslikkuse-noukogu
} 
government: "Now we can see how one saleswoman became prime minister and how others, street activists and uneducated people, became members of the government" (Beltadze, 2019). The Estonian high-ranking official expressed such judgments based on information that the Finnish Prime Minister had previously made public about herself: coming from a troubled family, working as a cashier before entering university and starting a political career.

Another representative of the Estonian Helme political dynasty, Martin Helme, also expresses gender-biased rhetoric. In his opinion, gender neutrality and feminism are misanthropic concepts. The desire for gender equality, according to Martin Helme, is contrary to human nature and extremely dangerous to society (Krashevskiy, 2017). Such approaches are being developed by another active member of EKRE, Jaak Madison, who voiced the party's position that full equality and gender neutrality are impossible (Raat, 2017). The public statements described above, in our opinion, are a manifestation of the liberal democracy revenge in Estonia, which intensified as a result of the 2019 parliamentary elections. The EKRE party also opposes the introduction of gender quotas in politics but does not oppose the entry of women into the party. As of September 1, 2020, the party has a women's wing, the EKRE Association, and if we turn to the personnel of the EKRE faction in the Riigikogu, has nineteen members, four of whom are women deputies. It should be noted that after the change of the Estonian government in early 2021, EKRE's position in power has weakened, although at the level of parliament and local authorities, this conservative party retains the option to lobby for anti-gender decisions.

Despite the feminization of higher education, Estonia has faced a significant gap between the wages of men and women. Estonia has long been in the group of countries with the highest wage gaps within the EU. In this country, new discriminatory practices in employment are recorded. It is women who are more likely to fall below the poverty line. (Hansson, Aavik, 2012; Narusk, Kandolin, 1997; Roosalu, 2013; Saar, Helemäe, 2016). Pandemic COVID-19 has strengthened these trends. The pay gap between men and women is immediately apparent in the first job and increases with age. With the most successful economies among countries with economies in transition, Estonia also has the largest gender pay gap in the EU. The national labor market is characterized by pronounced segregation: women are much more likely to hold low-income positions. In 2019, women's gross wages were 17.1\% lower than men's (Sooline palgalõhe väheneb, aga visalt, 2020). However, since 2013 there has been a steady positive trend - the pay gap is slowly but steadily declining.

Fewer women in employment, the difference in their wages compared with men, and the informal division of occupations between men and women all serve to block the full participation of women in the Estonian labor market. Lower payments to women indicate that the state and business value their work less. This affects the quality of life of Estonian women, creates women's economic dependence primarily on their partner. Also, a significant gap in wages has the prospect of a further significant gender gap in pensions. Because of these issues, reducing the gender pay gap should be a priority for Estonia in terms of measures to promote gender equality. 
Gender disparities in Estonian science are visible. Today, at least half of the graduate students are women; the proportion of females at the grassroots level of research careers is also high. However, the career gap between men and women is growing rapidly. Renowned Estonian female biochemist A. Kahru argues that the research career pyramid is currently showing a gender disparity in Estonia: while the number of degrees among men and women is about the same, the proportion of men is growing at the highest levels of academic careers. For example, $76 \%$ of professorships at the University of Tartu are held by men; decision-making bodies in the fields of education and science are headed mainly by men (and not only in the technical sciences) (Kahru, 2019, p. 65). Only 2 out of 12 members of the Research and Development Council, which advises the Estonian government, are women. Initiatives concerning the implementation of gender quotas for the formation of this advisory body, which were initiated several years ago, were not supported. As Estonian women have an even higher level of education than en, the community should be interested in making the most of their potential. However, this currently does not accord with the reality of the situation in this country.

It is noteworthy that the issue of gender equality in Estonian society has a somewhat negatively indifferent image: $65 \%$ of Estonians surveyed call this issue "a contrived problem"; most Estonians do not have a real interest in activism in the field of gender equality (Alas, Kaarelson, 2008, p. 18). There is no strong understanding in Estonian society at the level of public opinion that the creation of equal opportunities for genders enables more efficient use of human capital in Estonian society. It is especially significant in response to the increasing labor shortage in the country. It may take generations to change the attitude to the issue of gender parity. At the same time, the active forcing of the gender ideology introduced into the political and legal culture of Estonians (as well as Latvians and Lithuanians) may lead to positive results with regard to this issue, as was the case during the Soviet era. Reforms can be rapidly implemented thanks to the political will of the country leadership at the institutional level, while changes are much slower at the value level.

The topic of domestic violence is so acute for Estonia that even in her first speech on the occasion of the Independence Day of the Republic of Estonia, President K. Kaljulaid emphasized this issue. Every tenth reported crime is related to domestic violence. According to the Ministry of Justice of the Republic of Estonia, 4,119 crimes of domestic violence were registered in 2019, which increased by $14 \%$ compared to 2018 ; the number of reports about such illegal actions has also increased (Kuritegevus Eestis 2019, 2020). Obviously, these figures do not reveal the scope of the problem, as a much larger number of such illegal actions are not publicized. Thanks to the active position of President K. Kaljulaid, and other Estonian officials, as well as the liberal democratic segment of civil society, Estonia has now ended the stage of silence on domestic violence. Law enforcement has also changed its attitude towards this issue. Domestic violence is no longer perceived as a minor domestic illegal act that could be ignored by the relevant authorities. Gradually, the fight against domestic violence and measures aimed at its prevention are becoming an 
important part of the law enforcement agencies' activities in Estonia. Civil society institutions are also paying considerable attention to the issue. In Estonia, there is a network of support centers for those affected by gender-based violence, primarily domestic violence, at the level of state institutions.

Estonia is the only Baltic country to have ratified the Istanbul Convention. However, the process of discussing the document in the Riigikogu for ratification in 2017 showed a lack of unanimous support by Estonian politicians to the sensitive issues enshrined in the norms of this international legal document. In particular, the EKRE party faction did not support the ratified convention. Henn Põlluaasa, a member of the EKRE party, voiced EKRE's position: "I suspect that most deputies have not read the Istanbul Convention. Otherwise, we would not discuss this absurd and contrived document, but would immediately reject it....The Convention contains some extreme leftliberal and abnormal provisions that produce new sources of violence and repression, especially for those who value the family, morals and the traditional relationship between a man and a woman. According to the Convention, the traditional gender roles and customs are considered violence against women. Gender is only a socially constructed role, not the result of evolution,...This is a clear threat to security,... We do not need the Istanbul Convention',... because all forms of harassment, domestic violence, etc. are already regulated, banned and punished by law in Estonia" (Põlluaas, 2017). Currently, the main argument of the Istanbul Convention oppositions' denunciation is that this document is not much help in the fight for the rights of the affected from domestic violence, and, moreover, encroaches on traditional values, primarily on family values.

At the level of civic initiatives, the issue concerning the appropriateness of moving to gender-oriented budgeting has arisen in Estonia since 2008. There is currently no gender budgeting in Estonia, although the necessary conditions for its implementation exist. However, this first requires the political will for the parliament to decide on the integration of the gender component into the budget process. There is also no practice of gender analysis in Estonia, as a tool for improving national legislation.

\section{Conclusion}

Despite the revival of the women's movement, the ratification by the Baltic states of basic international legal instruments and progress in bringing national legislation in line with EU norms, Estonia, Latvia and Lithuania still have a gap between theoretical declaration of gender equality and actual gender inequality. The factor of European integration has become the main impetus for the Baltic states to carry out reforms in terms of the implementation of gender equality. However, anti-gender sentiments remain strong and are supported primarily by conservative, clerical actors, who ideologically rely on centuries-old patriarchal traditions and gender roles stereotypes.

The Baltic states, despite their membership in the EU, have not reached the standards of gender equality. Violations of women's rights still persist in various forms. Although the pace of the Baltic States in achieving gender parity 
is somewhat different (it is the slowest in Lithuania and the fastest in Estonia), all of the countries need to pay more attention to solving several common problems: reducing the gap between salaries and pensions; implementation of equal participation in decision-making processes policy; combating genderbased violence; introduction of gender-oriented budgeting and gender quotas, etc.

We see the biggest problem of the Baltic states in the implementation of gender equality in their narrow focus on the creation, at the request of the EU, of institutional mechanisms that would contribute to the implementation of gender equality. However, such actions do not help to change the value paradigm, which would establish an understanding of gender equality importance in the culture of the Baltic states' population. Gender equality as a liberal democratic value in the post-totalitarian Baltic states is being implemented very slowly and is met with rejection by broad sections of society. Instead, the family values of the patriarchal type are significant today. Traditional gender roles and gender stereotypes remain resistant to change in the post-Soviet Baltic states, despite the second decade of their membership in the EU. It confirms that the Baltic societies' demand for gender-oriented reforms is of low priority. The increase in the representation of populist, conservative, and nationalist political parties in the legislative and executive bodies of the Baltic states in recent years has intensified anti-gender rhetoric to preserve and protect traditional values.

The problem of guaranteeing gender equality has become particularly resonant in the terms of the COVID-19 pandemic. Women have been particularly vulnerable in terms of job retention, as quarantine restrictions have had a devastating effect on female-dominated professions. The Baltic states have become part of a global pandemic test of the still volatile gender equality principle. Women have faced new and more powerful challenges in balancing childcare, distance learning of their children and employment. A number of gender inequality manifestations that have long been practiced, risk becoming entrenched as "normal" in the post-pandemic world.

Note that various gender stereotypes and their destructive consequences, are characteristics not only of the Baltic states. Even those states that have high positions in gender indices, maintaining the image of rule-of-law states, now face manifestations of discrimination. However, the specificity of those postSoviet Baltic states, which have long been a part of the EU, lies in the slow liberal democratization and adaptation of the population to the values of the EU. The current rise of conservatism, populism, and right-wing radicalism is superimposed over the historical legacy of the Soviet past. Under such conditions, the implementation of gender equality is difficult and requires the political will of the leaders of the Baltic states. 


\section{References}

Alas, R., \& Kaarelson, T. (2008). Gender equality in post-socialist country: case of Estonia. Problems and Perspectives in Management, 6 (2), 1320.

Alyanak, L. (1999). Baltic blues: For women workers in Estonia, new jobs are lacking. World of Work: The Magazine of the ILO, 31, September/October, 16-17.

Apsauga nuo smurto artimoje aplinkoje: pasiūlyta nauja priemonè auku apsaugai (2020). Retrieved January 24, 2021 from https://socmin.lrv.lt/lt/naujienos/apsauga-nuo-smurto-artimojeaplinkoje-pasiulyta-nauja-priemone-auku-apsaugai

Bayer, J. (2002). Rechtspopulismus und Rechtsextremismus in Ostmitteleuropa. Österreichische Zeitschrift für Politikwissenschaft, 31(3), 265-280.

Beltadze, G. (2019). Helme: hoopis teie solvate Soomet. Retrieved December 10, 2020 from https://www.postimees.ee/author/99988

Čepaitienè, R. (2004). Feminizmas ir visuomenė Lietuvoje. Kultūros barai, 8/9, 23-29.

Concept Paper on Gender Equality Implementation (2001). Retrieved January 8, 2021

from

http://www.lm.gov.lv/upload/dzimumu_lidztiesiba/anglu/concept_pap er2001.pdf

Dahlerup, D. (Ed.) (2006). Women, Quotas and Politics. London: Routledge.

Dimitrova, A., \& Pridham, G. (2004). International actors and democracy promotion in Central and Eastern Europe: the integration model and its limits. Democratization, 11(5), 91-112. doi: 10.1080/13510340412331304606

Dimitrovs, A. (2012). Equality Law in Latvia: Current Trends and Challenges. The Equal Rights Review, 9, 11-23.

Directive (EU) 2019/1158 of the European Parliament and of the Council of 20 June 2019 on work-life balance for parents and carers (2019). Retrieved January 11, 2021 from https://eur-lex.europa.eu/legalcontent/EN/TXT/PDF/?uri=CELEX:32019L1158\& from=EN

Dzimumu līdztiesības politika Latvijā. Padziļināta analīze (2015). Brussels: European Parliament.

European Public Opinion Three Decades After the Fall of Communism (2019). Washington, D.C.: Pew Research Center.

Gender Equality Index. Estonia. 2019 (2020). Retrieved January 23, 2021 from https://eige.europa.eu/gender-equality-index/2019/EE

Gender Equality Index. Latvia. 2019 (2020). Retrieved January 23, 2021 from https://eige.europa.eu/gender-equality-index/2019/LV

Gender Equality Index. Lithuania. 2019 (2020). Retrieved January 23, 2021 from https://eige.europa.eu/gender-equality-index/2019/LT

Gender equality indicators. Violence (2020). Retrieved February 27, 2021 from https://w.csb.gov.lv/en/gender-equality-indicators/Violence 
Gender Equality Strategy 2020-2025 (2020). Retrieved March 5, 2021 from https://eur-lex. europa.eu/legalcontent/EN/TXT/PDF/?uri=CELEX:52020DC0152\&from=EN

Grachev, M., Rogovsky, N., \& Rakitski, B. (2007). Leadership and culture in Russia: The case of transitional economy. In J. S. Chhokar, F. C. Brodbeck \& R. J. House (Eds.), Culture and Leadership Across the World: The GLOBE Book of In-Depth Studies of 25 Societies (pp. 803832). New Jersey: Lawrence Erlbaum Associates.

Hansson, L., \& Aavik, K. (2012). The Effect of Gender and Ethnicity and Their Intersection on Work Satisfaction and Earnings in Estonia, 1993-2008. Studies in Transition States and Societies, 4, 3-19.

Irigaray, L. (1994). Thinking the Difference: For a Peaceful Revolution (K. Montin, Trans). New York: Routledge.

Jurenienè, V. (2010). Gender Roles in Lithuanian Society. Global Journal of Human Social Science, 10(6), 2-7.

Kahru, A. (2019). Male and female Estonian researchers or simply Estonian researchers? Estonian Research, 6, 65-67.

Kelemen, R. D. (2017). Europe's Other Democratic Deficit: National Authoritarianism in Europe's Democratic Union. Government and Opposition, 52(2), 211-238. doi: 10.1017/gov.2016.41

Kochenov, D., Magen, A., \& Pech, L. (2016). Introduction: The Great Rule of Law Debate in the EU. Journal of Common Market Studies, 54(5), 1045-1049. doi: $10.1111 / \mathrm{jcms} .12399$

Krastev, I. (2007). The Strange Death of the Liberal Consensus. Journal of Democracy, 18(4), 56-63. doi: 10.1353/jod.2007.0072

Krastev, I. (2016). What's Wrong with East-Central Europe? Liberalism's Failure to Deliver. Journal of Democracy, 27(1), 35-39. doi: 10.1353/jod.2016.0001

Krastev, I., \& Holmes, S. (2018). Explaining Eastern Europe: Imitation and Its Discontents. Journal of Democracy, 29(3), 117-128. doi: 10.1353/jod.2018.0049

Krastev, I. (2018). Eastern Europe's Illiberal Revolution. The Long Road to Democratic Decline. Foreign Affairs, 97(3), 49-56.

Krashevskiy, A. (2017). Martin Helme: Gender Neutrality and Feminism Misanthropic Concepts. Retrieved January 8, 2021 from https://rus.err.ee/612700/ martin-helme-gendernaja-nejtralnost-ifeminizm-chelovekonenavistnicheskie-koncepcii

Kuritegevus Eestis 2019 (2020). Retrieved January 16, 2021 from https://www.kriminaalpoliitika.ee/kuritegevuse-statistika/

Matonytè, I., \& Mejere, O. (2011). Politinio atstovavimo galimybiu pletra? Lietuvos parlamentaru požiūrio ì moteru kvotas analizé. Parlamento Studijos, 10, 99-127.

Mejere, O. (2012). Does Gender Matter in Governance? Gender Quotas as a Good Policy Tool: Practice and Failures in Lithuania. Social Research, 2(27), 46-61. 
Müller, J.-W. (2014). Eastern Europe Goes South. Disappearing democracy in the EU's Newest Members. Foreign Affairs, 93(2), 14-19.

Narusk, A., \& Kandolin, I. (1997). Social Well-Being and Gender: Post-Soviet Estonia and Welfare State Finland. Scandinavian Journal of Social Welfare, 6, 127-136.

Norris, P., \& Inglehart, R. (2019). Cultural Backlash: The Rise of Authoritarian-Populism. Cambridge: Cambridge University Press.

Paternotte, D., Kuhar, R. (2018). Disentangling and Locating the "Global Right": Anti-Gender Campaigns in Europe. Politics and Governance, 6(3), 6-19. doi.org/10.17645/pag.v6i3.1557

Pavilionienè, M. A. (2015). Lithuania: Pioneering Women's and Gender Studies in the Post-Soviet Baltic Republics. In R. Haas (Ed.), The Development of the Anglicist Women's and Gender Studies of Continental Europe (pp. 277-303). Warszawa: Peter Lang Publishing.

Plan for the Promotion of Equal Rights and Opportunities for Women and Men for 2018-2020 (2018). Retrieved January 15, 2021 from https://likumi.lv/ta/en/en/id/300170-plan-for-the-promotion-of-equalrights-and-opportunities-for-women-and-men-for-20182020

Põlluaas, H. (2017). Kõne Istanbuli konventsiooni ratifitseerimisel 20.09.2017. Retrieved December 14, 2020 from https://hennpolluaas.blogspot.com/2017/09/kone-istanbulikonventsiooni.html

Raat, S. (2017). EKRE peab sooneutraalsust ja feminismi inimvaenulikuks. Retrieved $\quad$ February 13, 2021 from https://jarvateataja.postimees.ee/4208941/ekre-peab-sooneutraalsustja-feminismi-inimvaenulikuks

Roosalu, T. (2013). Income Inequality and Equality. In M. Heidmets (Ed.), Estonian Human Development Report, 2012/2013 (pp. 114-122). Tallinn: Eesti Koostöö Kogu.

Saar, E., \& Helemäe, J. (2016). Differentiated Educational Pathways and Gender Inequalities in the Estonian Labour Market: What Is the Impact of the Systemic Change? In T. Roosalu \& D. Hofäcker (Eds.), Rethinking Gender, Work and Care in a New Europe (pp. 325-347). London: Palgrave Macmillan.

Sagatys, G. (2010). The Concept of Family in Lithuanian Law. Jurisprudence, 1(119), 181-196.

Sedelmeier, U. (2014). Anchoring Democracy from Above? The European Union and Democratic Backsliding in Hungary and Romania after Accession. Journal of Common Market Studies, 52(1), 105-121. doi: $10.1111 / \mathrm{jcms} .12082$

Sooline palgalôhe väheneb, aga visalt (2020). Retrieved February 11, 2021 from https://kompetentsikeskus.sm.ee/2020/07/22/sooline-palgalohevaheneb-aga-visalt/

Szent-Iványi, B., \& Tétényi, A. (2008). Transition and foreign aid policies in the Visegrád countries. A path dependent approach. Transition Studies Review, 15(3), 573-587. doi: 10.1007/s11300-008-0021-6 
Szomolány, S., \& Gál, Z. (2016). Slovakia's Elite: Between Populism and Compliance with EU Elites. In J. Pakulski (Ed.), The Visegrad Countries in Crisis (pp. 67-86). Warszawa: Collegium Civitas.

The Constitution of the Republic of Latvia (2016). Retrieved January 12, 2021 from www.president.lv/en/republic-of-latvia/the-constitution-ofthe-republic-of-latvia\#gsc.tab $=0$

Ühtekuuluvuspoliitika fondide võrdõiguslikkuse kompetentsikeskus (2020). Retrieved December 20, 2020 from https://kompetentsikeskus.sm.ee/2020/07/22/sooline-palgalohevaheneb-aga-visalt/

Verloo, M. (2018). Gender Knowledge, and Opposition to the Feminist Project: Extreme-Right Populist Parties in the Netherlands. Politics and Governance, 6(3), 20-30. doi.org: 10.17645/pag.v6i3.145

Žalėnienè, I., Krinickienè, E., Tvaronavičienè, A., \& Lobačevskytė, A. (2016). Gender Equality and its Implementation in Universities of Lithuania. Economics and Sociology, 9(1), 237-251. doi: 10.14254/ 2071789X.2016/9-1/16

Žvinkliené, A. (2009). Gender Gap or Signs of Patriarchy in the Baltic States: Case of Lithuania. Sociologija. Mintis ir veiksmas, 240, 99-118. 